\title{
Reproductive Response in Offspring Male Rats Exposed to Prenatal Stress and to Early Postnatal Stimulation
}

\author{
Respuestas Reproductivas en Ratas Estresadas Prenatalmente, Expuestas a Estimulación Postnatal
}

\author{
Chen Cárdenas, S. M.*; Mayer, N.*; Romanini, M. C.**; Rolando, A. N.**; \\ Liaudat, A. C."; Brun N.*; Vivas, A.*; Gauna, H. F.* \& Rodríguez, N.*
}

CHEN CÁRdenAS, S. M.; MAYER, N.; ROMANINI, M. C.; ROLANDO, A. N.; LIAUDAT, A. C.; BRUN, N.; VIVAS, A.; GAUNA, H. F. \& RODRÍGUEZ, N. Reproductive response in offspring male rats exposed to prenatal stress and to early postnatal stimulation. Int. J. Morphol., 31(2):754-764, 2013.

SUMMARY: Stress in pregnant rats alters the pattern of secretion of corticosterone (COR) and modifies transplacentally hypothalamic-pituitary-adrenal axis (HPA) fetus. Prenatal stress during the critical hypothalamic differentiation is related to decreased fertility of male offspring by an increase in the basal level of COR. This modification could induce long-term changes in the process of apoptosis in the testis. However, early postnatal handling increases maternal behavior and could reverse the effects caused by increased secretion of COR. The aim of this research was to investigate the effects of early postnatal stimulation of male rats prenatal stressed by chronic immobilization during the last two weeks of pregnancy, on the hypothalamic-pituitary-gonadal axis and their relationship with the activity of the HPA. Male Wistar rats 3 month olds, were separated in four groups: (a) prenatally stressed animals by immobilization (IMO), without postnatal stimulation; (b) prenatally stressed animals with postnatal stimulation; (c) control animals without prenatal stress, without postnatal stimulation and (d) control animals without prenatal stress, with postnatal stimulation. In different animals groups plasmatic levels of COR, Testosterone (T) and Luteinizing Hormone (LH) were analyzed. Gonadosomatic index and testicular apoptosis was determined. In conclusion that prenatal stress by IMO increased levels of COR and inhibits the HHG axis obtaining low values of plasmatic LH and T, testicular weight, and induction of apoptosis in testes. On other hand, early postnatal stimulation results in an increase in maternal care to the offspring reversing the effects of prenatal stress on the HPG axis. This effect could be mediated by a mechanism independent of the HPA axis.

KEY WORDS: Early postnatal stimulation; Prenatal stress; HPA axis; HPG axis; Rats; Apoptosis.

\section{INTRODUCTION}

Studies in our laboratory, determine that the application of stress stimuli during pregnancy in rats affects the male offspring hypothalamic-pituitary-gonadal (HPG) axis, in sexually mature animals, and it also produces low birth weight (Rodríguez et al., 2007). There is growing evidence that gestational stress can, in humans, be associated with an increased incidence of preterm birth and low birth weight (Hobel et al., 2008; Bonari et al., 2004; Pretch et al., 2007) and an alteration of sexual function (Ward, 1972). Exposure to high levels of prenatal stress can adversely affect fetal brain development (Kinney et al., 2008). Gene deregulation, destruction of neurons and synapses, the inhibition of dendritic development (Lou et al., 1994), are some of the mechanisms by which maternal stress affects fetal neurodevelopment.
The activation of hypothalamic-pituitary-adrenal (HPA) axis during stress limits the efficiency of reproduction. Stress reduces the frequency and amplitude of gonadotropin releasing hormones $(\mathrm{GnRH})$ and lutinizing hormone $(\mathrm{LH})$ pulses, that which decreases the gonadotropic funtion (Dobson et al., 2003). The actions of corticosterone (COR) prenatally stressed offspring on neuroendocrine and autonomic systems alters fetal reproductive function (Zarrow et al., 1970).

Exposures to appropriate levels of testosterone (T), acting through its metabolite, estradiol, during this period, is critical for the development of neural circuits that govern sexual behavior, control the secretion of gonadal hormones and allow ultimately to establish various morphological

\footnotetext{
* Departamento de Biología Molecular Facultad de Ciencias Exactas, Universidad Nacional de Río Cuarto, Argentina.

** Departamento de Anatomía, Facultad de Agronomía y Veterinaria, Universidad Nacional de Río Cuarto, Argentina.
} 
indices (Ward \& Ward, 1985; Chantal et al., 1996; Döhler et al., 1984; Gorski, 2002). In male rats there is a surge in plasma T during 18 and 19 gestation days (Ward \& Weisz, $1980 ; 1984)$, and again during the first few hours following birth (Baum et al., 1988; Lalau et al., 1990; Slob et al., 1980).

Prenatal stressed males show lower than normal levels of plasma T on days 18 and 19 of gestation (Ward \& Weisz, 1980; 1984). The increase of T on day 18 of gestation can be disrupted by stress of the mother or by the administration of antiandrogens such as cyproterone acetate, in which case demasculinization occurs in the male offspring (Weiz et al., 1982; Perakis \& Stylianopoulou, 1986). This demasculinization includes changes in sexual behavior control and in the release of gonadotrophins (Gorski et al., 1980; Montano et al., 1995).

Prenatal stress during the critical hypothalamic differentiation is related to decreased fertility and fecundity (Anderson et al., 1986) and leads to changes in reproductive behavior in males and females (Ward, 1984; Ward et al., 2002). Prenatal stress affects adult reproductive behavior by altering the HPG axis regulation (Szuran et al., 2000).

Acute stress there has found increased levels of $\mathrm{T}$ in plasma, whereas when stress is chronic, these levels are reduced (Allouche et al., 2009). Several studies indicate that chronic stress causes gonadal atrophy and reduces sexual activity in males and females (López-Calderón et al., 1990).

During the formation of the testis, the stage in which gonocytes differentiate into spermatogonias, apoptotic index is high and is known as the "first sign of spermatogenesis". This happens at 3 days after birth in rats (Rooij, 1998) and its purpose is to adjust the number of cells as the testis grows.

The total cell number in seminiferous epithelium, in the testis, is determined by a dynamic balance between cell proliferation and apoptosis (Hikim et al., 2003; Shaha, 2008). The regulation of apoptosis is a key factor to achieve this balance by removing unnecessary or damaged cells that might otherwise have adverse effects on the body (Zhang $e t$ al., 2007).

The apoptotic process is activated trough two pathway, one intrinsic and other extrinsic. Both pathways converge on caspase 3 and other executing caspase and nucleases that drive the terminal events of programmed cell death (Cory et al., 2002). The population of Sertoli cells and germ cells are regulated during the "first sign of spermatogenesis" by endocrine signals, including hormone stimulating follicle (FSH), luteinizing hormone (LH) and T (Ruwanpura et al., 2008, 2010). Hormonal factors such as alteration of T, FSH and LH (Tripathi et al., 2009; SinhaHikim et al., 1995) cause germ cell apoptosis and massive loss of the same in the testis. Maternal behavior appears to be one of the factors responsible for changes in HPA axis activity of the offspring, suggesting that the behavior of the mother "programs" the HPA axis response of the offspring to stress in adulthood (Liu et al., 1997). Handling increases maternal behavior and reduces stress caused by the secretion of corticosterone in adult offspring (Maccari et al., 1995). The increased frequency of arch-backed nursing $(\mathrm{ABN})$ and Licking \& Grooming (LG) are the behavioral changes that the offspring are receiving from their mothers, which have demonstrated long-term effects on neurobiology and behavior of pups (Liu et al.; Francis et al., 1999).

The major known changes in the HPA axis caused by postnatal handling are reduction in initial HPA response to stress and the duration of it. Therefore, these changes prevent emotional reactivity (Wakshlak \& Weinstock, 1990; Weinstock, 1997). Increased glucocorticoid receptor (GR) hippocampal and increased mRNA expression of the same improve the sensitivity of negative feedback and consequently decrease the levels of hypothalamic CRH mRNA (Liu et al.). Because of this, there is a decrease of COR levels after stress (Ogawa et al., 1994; Le Moal et al., 1995).

The purpose of the present study is to find whether early postnatal stimulations reverse alterations in the reactivity of the hypothalamic-pituitary-gonadal axis and in the testicular function caused by prenatal stress in male offspring, and to investigate whether this effect on the HHG is mediated by apoptosis

\section{MATERIAL AND METHOD}

Albino Wistar rats were housed with ad libitum access to food and water. They were housed and maintained under lab standard conditions at $22 \pm 2^{\circ} \mathrm{C}$, controlled photoperiod of $12 \mathrm{~h}$ (lights on 7:30 a.m. to 7:30 p.m.), and room humidity. Male-female pairs were housed together overnight, and the next morning; a vaginal smear was obtained and examined microscopically for the presence of sperm (day 1 of pregnancy). Prenatal stress: Chronic stress by immobilization (IMO) was applied to the experimental group females. Rats were immobilized (Bertuzzi et al., 2003) on a wooden board $(20 \times 20 \mathrm{~cm})$ by taping their four limbs to metal mounts, according to the method described Michajloskij et al. ,(1988). Each female was subjected to a 30 min stress session, during the last two weeks of pregnancy, three times per week, at different moments of the morning on different days. Con- 
trol female rats were left undisturbed in their home cages. The offspring males from these two groups were referred to as prenatal stress (PS) and control (PC).

Early postnatal handling. The PS group was assessed to two groups: prenatal stress and handling as described by Meaney et al. (1987) $\mathrm{n}=10(\mathrm{PSH})$ and prenatal stress and non-handling $\mathrm{n}=10$ (PSNH). The PC group was divided into two groups: prenatal control and handling $\mathrm{n}=10(\mathrm{PCH})$ and prenatal control and non-handling $\mathrm{n}=10(\mathrm{PCNH})$. Within 24 $\mathrm{h}$ of birth, litters were culled to eight pups to prevent the influence of number of pups on the studies parameters. All groups were house in the same animal room, and all pups were kept together with their mothers. Postnatal handling was performed daily from postnatal day 1 until postnatal day 3. Briefly, the pups were picked up and transferred from their home cage to another one containing paper toweling. Separate cages were used for each litter throughout in the cage for $1 \mathrm{~min}$ (between 9 to 11 a.m. every day) before being returned to their home cage. The mother was taken out of the home cage before de pups, kept alone in another cage for the $1 \mathrm{~min}$, and then returned to the home cage after the pups. Handling sessions were always performed in the same room by the same experimenter. Offspring were weaned 21 days after birth and housed in groups of four males by litter, and left undisturbed until testing at 90 days of age. Only two male siblings per litter from each group were tested in adult life.

Blood Sample. All the determinations were performed in male offsprings at 90 days of age. Blood sample (heparinized tube) were taken between 9 and 12 a.m. and immediately after removal from the home cage. COR, TES and LH levels were determined in heparin plasma samples. Control, prenatal stressed and postanatal handling animals were sacrificed by decapitation. Plasma was stored at $-20^{\circ} \mathrm{C}$.

Corticosterone assay. Plasma corticosterone levels were measured by radioimmunoassay (Krey et al., 1975) wing a sheep antibody with high specificity (TECNOLAB). The Corticosterone standards were supplied by Sigma Chemical $\mathrm{CO}$. The radioactive steroids were $(0.25 \mathrm{mCi})$ corticosterone, $[1,2,6,7-3 \mathrm{H}(\mathrm{N})]-3.0 \mathrm{~TB} \mathrm{q} / \mathrm{mmol}(80.00 \mathrm{Ci} / \mathrm{mmol}) 0.25$ $\mathrm{ml}$ of ethanol. Sciences, Inc. Boston, MA. The intra and interassay coefficients of variation were $8.8 \%$.

Testosterone assay. Determinations of testosterone levels were carried out wing the Coated Tube I125 RIA Kit, COATA- COUNT. Total Testosterone. DPC-Diagnostic Products Corporation, Los Ángeles CA.

Luteinizing hormone assay. Plasma LH concentration were measured using the Kit for rat LH I125 RIA (AHR002)
Biocode - HYCEL (Diagnos Med SRL). The sensibility of the LH assay was $0.3 \mathrm{pg} /$ tube, with $4.2 \%$ intra assay variability.

Index Gonadal-somatic. Gonads were extracted to determine the gonadal-somatic index. Using the following equation:

Gonadal-Somatic Index: (Gonadal weight/Corporal weight) x 1000

Active Caspase-3. Immunochemistry technique (Bullock $\&$ Petrusz, 1983) was used to identify the cells that synthesize active caspace 3 . All animal grups were sacrificed by decapitation. The testes glands obtained were fixed in $4 \%$ formaldehide phosphate buffer ( $\mathrm{pH} 7.6)$, for 10 hours. Then they were rinsed in PBS, dehydrated through an alcohol ascending grades cleared in xylene and paraffine embedded. Tissue cuts of turn thick were deparaffinized, hydrated and $\mathrm{H}_{2} \mathrm{O}_{2}$ treated to block endogenous peroxidase. They were treated with horse normals serum (2\% in PBS) and incubated overnight at $4^{\circ} \mathrm{C}$ with specific antibodies. After washing, they were treated with the second biotinilate antibody (antirabbit developed in goat) (Vector Laboratories, USA) for an hour at room temperature and then rinsed again in PBS and treated with Avidine-Biotine-immunoperoxidasa kit (ABC, Vectastain, Vector Laboratories). Finally, the sections were incubated with 3-3'-diaminobencidine, in the presence of $\mathrm{H}_{2} \mathrm{O}_{2}$ to reveal peroxidase expression sites. The reaction was stopped in distilled water. Active caspase-3 (Chemicon International, USA) were used to determine the apoptotic way.

TUNEL Immunocytochemical Technique. Twelve alternate sections were processed from each of $\mathrm{PCNH}, \mathrm{PCH}$, PSNH, PSH animal groups. The hydrated sections were incubated with K-proteinase during 8 - $10 \mathrm{~min}$ in wet chamber. Endogen peroxidase blocking was done with $3 \%$ hydrogen peroxide following the protocol provided by the Apoptag Plus "in situ Apoptosis. Peroxidase kit" (Oncor, USA). Negative control did not include the terminal transferase desoxinucleotidyl transferase enzyme (TdT); in the positive control, post-lactation mammary gland was used. Normal nuclei were identified using $1 \%$ methyl green nuclear contrast coloration.

Images Stereological Analysis. Quantification of apoptotic and normal nuclei was performed using the System KS-300 v. 3.0 (Kontron/ Zeiss) and the elaboration of an "ad-hoc" macro program. Seven to ten images of each zone were digitalized from each histological section totalizing 750 images. A Zeiss Axioscope microscope with a built in 3.2 Mpx Sony digital camera was used. 
Statistical analysis. The statistical comparisons were analysed using two-way $2 \times 2$ ANOVA, between: mother treatment (prenatal stress) and offspring (postnatal handling). Post-hoc comparisons were made using Duncan's test. These values were expressed as means ( \pm SEM), with $p<0.05$ considered a statistically significant difference.

\section{RESULTS}

The statistical analysis two way ANOVA showed that the effects of the prenatal stress treatment and postnatal manipulation on the plasma COR levels (Fig. 1) for PCNH, PCH, PSNH and PSH groups were significant for prenatal stress treatment $(F(1,41)=40.32$;

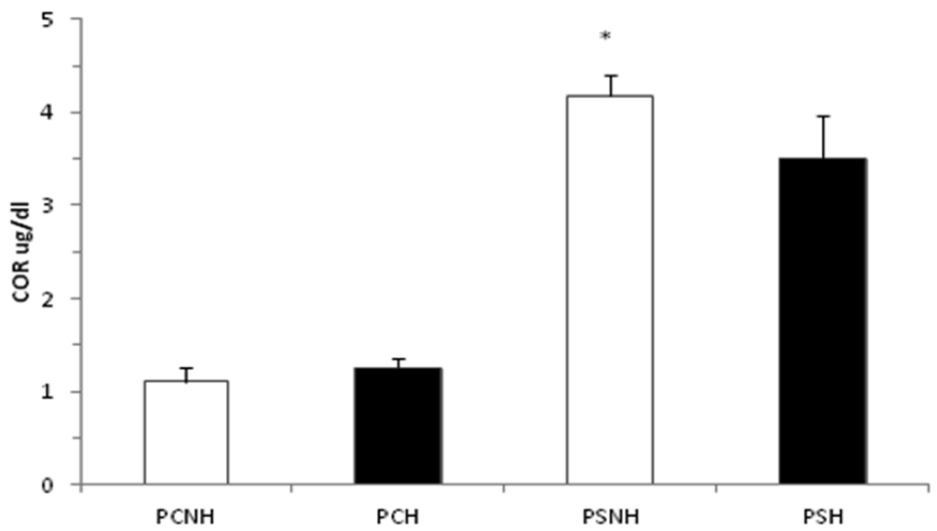

Fig 1. Effect of prenatal stressed adults offspring without handling PS-NH $(n=9)$ on plasma COR levels, and with manipulation PS-H $(n=15)$, control adult male offspring PC-NH ( $\mathrm{n}=7)$, control adult male offspring with handling PC-H $(n=14)$. Each bar represents the mean \pm SEM (standard error of the mean). *p $<0.05$ between PS-NH vs PC-NH and PCH.

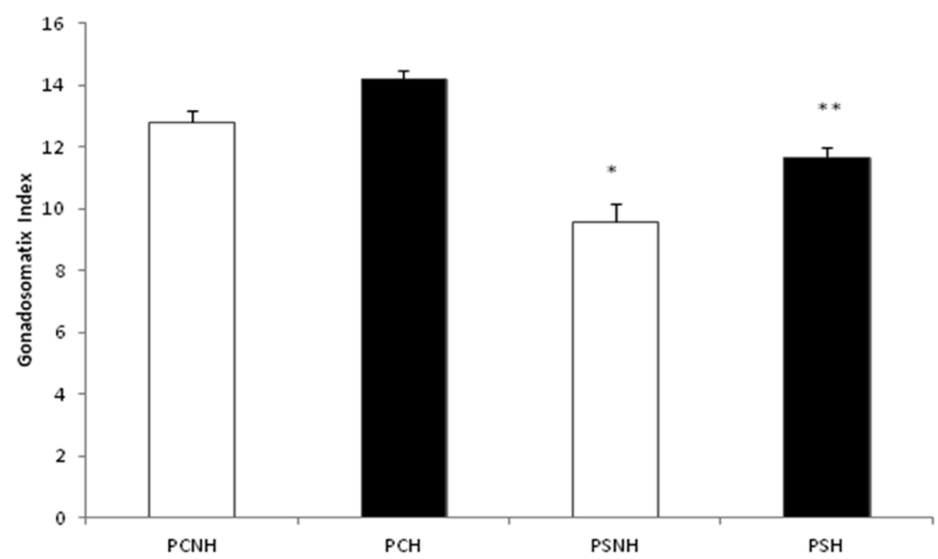

Fig. 2. Gonado-somatic index of prenatal stressed adults offspring without handling PS-NH $(n=5)$ and of prenatal stressed with postnatal handling PS-H $(n=10)$, controls offspring rats without handling PC-NH $(n=5)$ and with postnatal handling $(n=7)$. Each bar represents the mean \pm SEM (standard error of the mean). ${ }^{*} \mathrm{p}<0.05$ between PS-NH vs. PC-NH and PCH. ** $\mathrm{p}<0.05$ between PSH vs. PSNH. $\mathrm{p}=0.012)$, and postnatal treatment $(\mathrm{F}(1,41)=$ $559.67 ; \mathrm{p}=0.055)$. The post-hoc test showed that the basal plasma COR levels in PS-NH animals (4.18 $\pm 0.12 \mu \mathrm{g} / \mathrm{dL}$ ) were significantly higher than in PCNH animals $(1.10 \pm 0.15 \mu \mathrm{g} / \mathrm{dL} ; \mathrm{p}=0.0047)$. Both groups of animals PSNH and PSH showed a significant rise in plasma COR levels with respect to basal levels PCNH and PCH ( $p<0.05)$.

The ANOVA demonstrated a significant effect in the following parameters: prenatal stress treatment $(\mathrm{F}(1,23)=10,97, \mathrm{p}=0,0028)$; and postnatal treatment $(\mathrm{F}(1,23)=14.73, \mathrm{p}=0.035)$. The interaction between both factors was also significant $(F(1,23)=1.52 ; p=0.022)$. The differences in gonadal-somatic index were significant between PSNH vs. PCNH and PCH *p $<0.05$; and between PSH vs. PSNH $* *$ p $<0.05$ (Fig. 2). The PSNH animals showed a significant decrease in the gonado-somatic index compared with $\mathrm{PCNH}$ or $\mathrm{PCH}$ groups. When prenatally stressed group were postnatally stimulated $\mathrm{PSH}$, this effect reversed significantly, matching the gonado-somatic index with PCNH group.

The statistical analysis two way ANOVA showed that the effects of the prenatal stress treatment and postnatal manipulation on the plasma Luteinizing Hormone levels (Figure 3) for PCNH, $\mathrm{PCH}, \mathrm{PSNH}$ and PSH groups were significant for prenatal stress treatment $(\mathrm{F}(1,20)=14.86 \mathrm{p}=0.0004)$ and postnatal treatment $(\mathrm{F}(1,20)=4.44 \mathrm{p}=0.0421)$. The interaction between both factors was also significant $(\mathrm{F}(1,20)=1.84 ; \mathrm{p}=0.031) . * \mathrm{p}<0.05$ between PSNH vs. PCNH and PCH ; ** p $<0.05$ between PSH vs. PSNH. PSNH animals showed a significant decrease in plasma $\mathrm{LH}$ levels with respect to the control PCNH and $\mathrm{PCH}$ groups. When the prenatal stressed animals were postnatal stimulated PSH, prenatal stress effect was significantly reversed.

The statistical analysis two way ANOVA showed that the effects of the prenatal stress treatment and postnatal manipulation on the testosterone levels (Fig. 4) for PCNH, PCH, PSNH and PSH groups were significant for prenatal stress treatment $(\mathrm{F}(1,41)=15.68 \mathrm{p}=0,091))$ and postnatal treatment $(\mathrm{F}(1,41)=54.41 \mathrm{p}=0.0031)$ The interaction between both factors was also significant $(\mathrm{F}(1,41)=5.74 ; \mathrm{p}=0.004) . * \mathrm{p}<0,05$ between PSNH vs. PCNH and PCH; ** p $<0.05$ between PSH vs. PSNH. PSNH animals showed a significant 

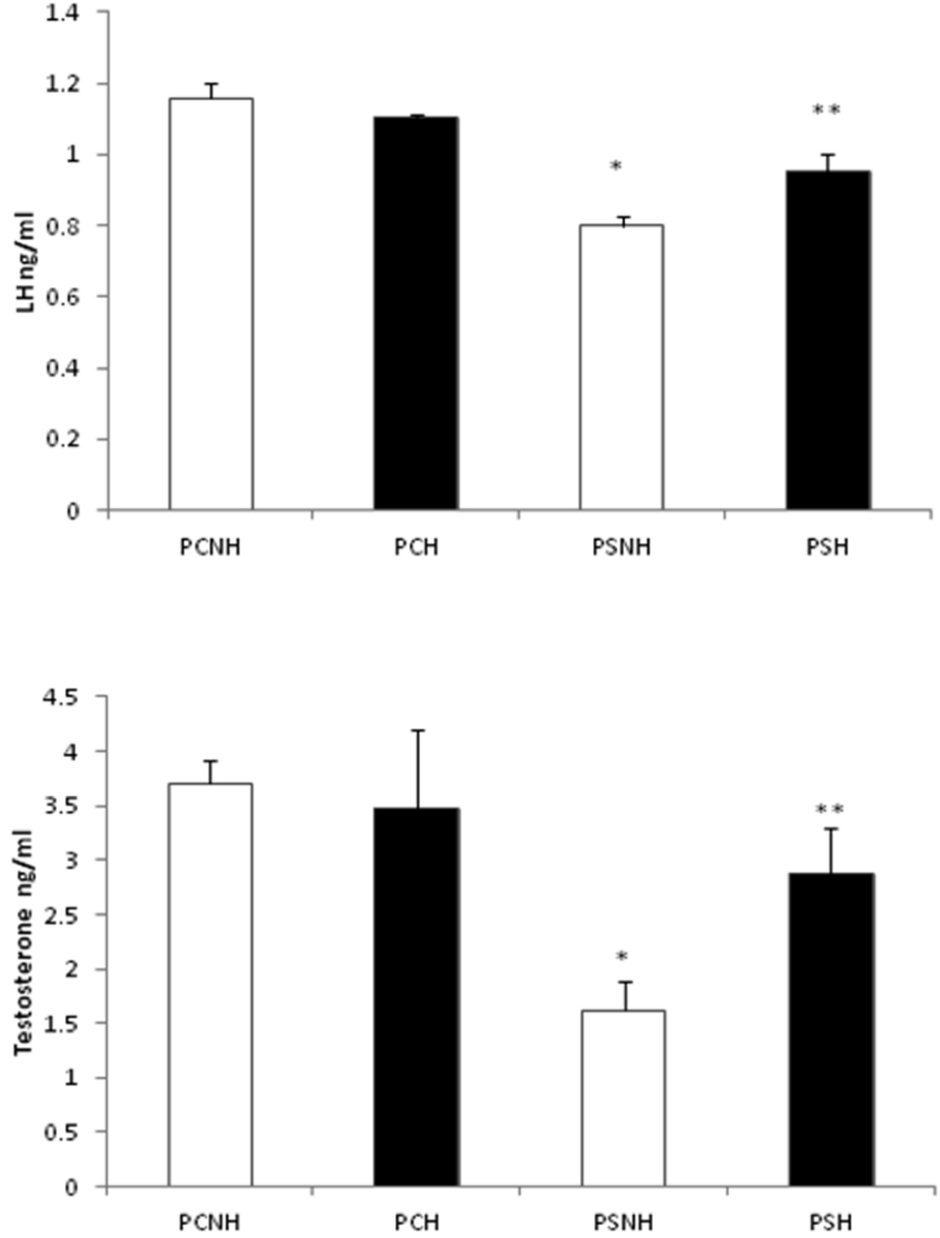

Fig. 4. Effect of prenatal stressed on the testosterone levels in adults offspring without manipulation PS-NH $(\mathrm{n}=14)$, and with manipulation PS-H ( $n=9)$, control adult male offspring PC-NH ( $n=12)$, control adult male offspring with manipulation PC-H $(n=10)$. Each bar represent the mean \pm SEM (standard error of the mean). $* p<0.05$ between PS-NH vs. PC-NH and PCH. ** $\mathrm{p}<0.05$ between PS-H vs PS-NH.

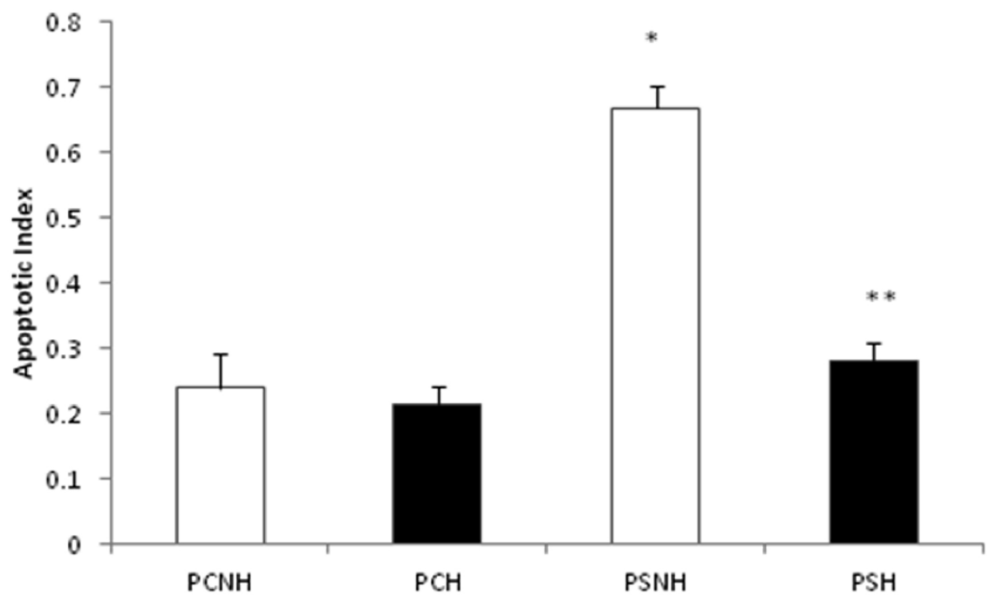

Fig. 3. Effect of prenatal stressed adults offspring without manipulation PS-NH $(n=6)$ on plasma Luteinizing Hormone levels, and with manipulation PS-H $(n=6)$, control adult male offspring PC-NH $(n=6)$, control adult male offspring with manipulation PC-H $(n=6)$ Each bar represents the mean \pm SEM (standard error of the mean). $* \mathrm{p}<0.05$ between PS-NH vs. PC-NH and PCH. ** $\mathrm{p}<$ 0.05 between PS-H vs. PS-NH.

decrease in plasma testosterone levels with respect to the control PCNH and $\mathrm{PCH}$ groups. When the prenatal stress animals were stimulated postnatal PSH, prenatal stress effect significantly reversed.

The two way ANOVA showed that the effects of the prenatal stress treatment and postnatal manipulation on testicular glands apoptotic index (Figure 5) for PCNH, PCH, PSNH and PSH groups were significant for prenatal stress $(\mathrm{F}(1,35)=44.21$; $\mathrm{p}=0.012)$ and postnatal handling treatment $(\mathrm{F}(1,35)$ $=30.16 ; \mathrm{p}=0.021)$. The interaction between both factors was also significant $(F(1,35)=23.24 ; p=$ $0.011) .{ }^{*} \mathrm{p}<0.05$ between PS-NH vs. PCNH and PCH. $* * \mathrm{p}<0,05$ between PS-H vs. PSNH groups.

It found that those animals receiving prenatal stress PSNH showed a significant increase in testicular glands apoptotic index compared with control PCNH and PCH groups. When the prenatally stressed animals were stimulated postnatal PSH this effect is reversed. Prenatally stressed animals with postnatal stimulation have similar values that control groups.

In the epithelium of the seminiferous tubules from PS-NH group, were observed numerous apoptotic cells detected by TUNEL. Positive staining was observed most frequently in the spermatogonia nuclei (Fig. 6). To determine one the apoptotic pathway was inmunolabeled with active caspase 3 , in this same group in the same way the mark was located in the spermatogonia (Fig. 7).

Fig. 5. Testicular glands apoptotic index of prenatal stressed adults offspring without postnatal manipulation PS-NH $(\mathrm{n}=10)$ and of prenatal stressed with postnatal manipulation PS-H $(n=10)$, controls offspring rats without manipulation PC-NH $(\mathrm{n}=10)$ and with postnatal manipulation $(n=9)$. Each bar represents the mean \pm SEM (standard error of the mean). ${ }^{*} \mathrm{p}<0.05$ between PS-NH vs. PC-NH and PC-H. ** p $<0.05$ between PS-H vs. PS-NH. 


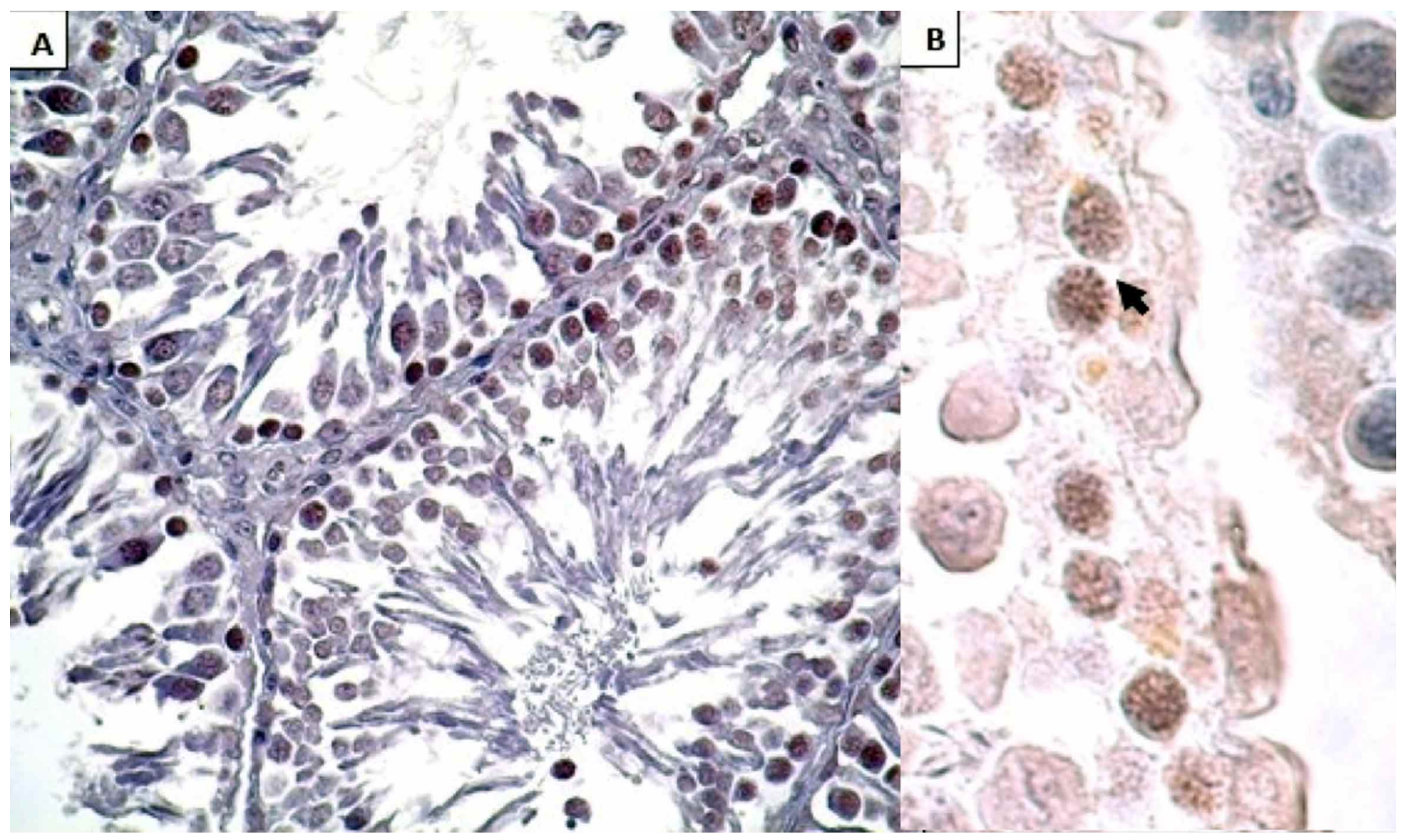

Fig. 6. Testes from PS-NH group, stained with TUNEL-technique. TUNEL-positive spermatogonia nuclei (arrow). A: (400x) and B: (1000x).

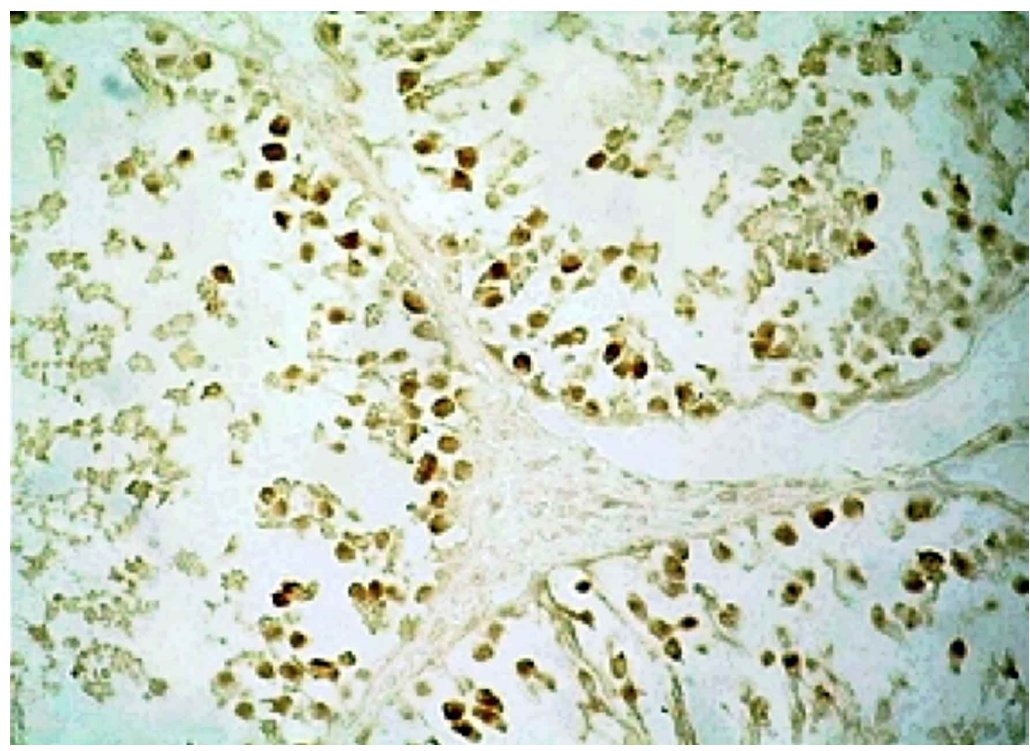

Fig. 7. Testes from PS-NH group. Immunostaining for Active caspase-3, was localized in spermatogonia (400X).

\section{DISCUSSION}

Chronic prenatal stress immobilization, applied over unpredictable and inescapable conditions, produces, in adult male offspring rats, decreased testicular size, a finding consistent with those obtained by Dahlof et al.,
(1978). This effect of prenatal stress would occur through the reduction of aromatase enzyme activity in the hypothalamus (Rhees et al., 1996) and steroidogenic d-3-bhydroxysteroid dehydrogenase in the testis (Orth et al., 1983), during the critical period of fetal gonadal development. When these animals were postnatally stimulated it reversed the decrease in the size of the testis caused by prenatal stress.

Plasma LH levels decreased by prenatal stress in adult animals. As consequence, plasma testosterone levels were reduced by prenatal stress. These results are consistent with the findings of Lopez-Calderón et al. and Silva et al. (1998), by high intensity chronic stimulus. Also prenatal stress leads to a lack of tonic gonadotropin secretion, which is responsible for TES levels in adult males (Arena \& Pereira, 2002). The inhibitory effect of CRH on LH secretion seems to by mediated by the opioidergic neurons, since inhibitory role of CRH in suppressin LH secretion has been reported to be blocked by opioidergic antagonist (Petraglia et al., 1986). 
HPG axis alterations found in prenatal stressed adult offspring influence on the sexual differentiation brain male rats (Anderson et al.; Ward, 1972, 1984; Ward \& Weisz, 1980). This would generate incomplete masculinization of the central nervous system.

The high sensitivity of HPG axis to stress produced similar results when the stress is applied in adult rats. Sinha Hikim \& Swerdloff (1999), working with heat stress and chemotherapeutic agents in adult animals, found a decrease in amplitude and frequency $\mathrm{GnRH}$ pulses, resulting in testicular atrophy, decreased spermatogenesis and decreased TES production.

The application of postnatal stimulation reversed the effect on LH and TES, levels returning to normal levels. This effect of postnatal handling on LH secretion could be mediated opioids pathway.

On the other hand, chronic prenatal stress, unpredictable and inescapable, for immobilization in the last two weeks of gestation, increases basal COR plasma in adult male offspring (Mayer et al., 2011). This effect would be caused by high levels of COR produced by the pregnant mother, in response to stress. This hormone cross the placenta and affects various fetal organs and tissues (Zarrow et al.; Patrick et al., 1981). The excess maternal glucocorticoids disrupts the fetal circadian clock, through action on the glucocorticoid receptors are notably present in the Central Nervous System (CNS) during early development (De Kloet et al., 1988). As a result, there is an increasing blood COR levels. Different studies show that these results may have been caused by the decreased number of mineralocorticoid receptors present in offspring hippocampus (Barbazanges et al., 1996; Maccari et al., 2003), which are the main substrates of negative feedback control of adrenal glucocorticoid secretion under basal conditions (De Kloet \& Reul, 1987). When EP animals are postnatal handling, plasma COR levels remain high. These finding are consistent with the results of receptor binding studies showing that handling increases hippocampal glucocorticoid receptor, but not mineralocorticoid receptor density. Thus the increase in glucocorticoid receptor binding in handled animals is likely associated with altered rates of receptor biosynthesis. Moreover the handling effect is quite specific, altering glucocorticoid receptor, but not mineralocorticoid receptor mRNA expression. The mecanism (s) whereby glucocorticoid receptor gene expression is permanently increased by postnatal handling remains to by determined (O'Donnell, 1994).

These findings are in line with other studies that found that treatment of pregnant mothers with COR or ACTH analogues had similar consequences to those of prenatal stress, suggesting that glucocorticoids may negatively influence the TES synthesis during fetal development (Lalau et al.).

The results of this study on apoptosis in the testis showed that those animals receiving prenatal stress, had an increased apoptotic index. The increase in testicular apoptosis is presumably the result of endocrine changes. The decline of gonadotropins and testosterone influence the cellular testis events (Young \& Nelson, 2001). In this sense, Nandi et al. (1999) found that testosterone is a survival factor for testicular germ cells, since testosterone decrease induces apoptosis testis and on the contrary TES secretion can reduce apoptosis in some situations. This effect is consistent with other obtained by Gerardin et al. (2005), who found that simply TES replacing at birth in offspring male exposed to prenatal stress during differentiation sexual period, is able to reverse changes in sexual behavior, normalizing anogenital distance, decrease latency in the first mount, acting similarly to the effect of early stimulation.

The results of this study indicate that testicular apoptosis is caspase 3 dependent, coinciding with the findings of Kim et al. (2001), who in a study of testicular tissue found that germ cell apoptosis is consequent of reducing the intratesticular TES concentration. Because of spermatogonia become the major cell types in producing apoptosis in adult rats. Sinha-Hikim et al. (2003), Moreno et al., (2006) and Tripathi et al., reported that the testis uses the extrinsic and intrinsic pathways to induce apoptosis in their cells. Both pathways converge on caspase 3 and other caspases and nucleases that drive executing terminal events of apoptosis (Cory \& Adams). Similar studies conclude that the signaling system FAS / FasL is involved in the induction of apoptosis in germ cells (Nandi et al.; Young \& Nelson, 2001; Riccioli et al., 2003) and Sertoli cells (Riccioli et al., 2000) of rats after testosterone decline.

Prenatal stress and postnatal stimulation produce opposite effect. It is found that postnatal stimulation significantly reversed the effects of prenatal stress, leading to normal values. Thus, our findings agree with other authors (Gao et al., 2002). Decrease of apoptotic index, produced by postnatal stimulation in prenatal stressed animals, would generate through the modification of certain parameters of the mother's behavior, such as brood care (Levin \& Stern, 1975), within which we can highlight the time the mother goes to licking them (Barbazanges et al.). The frequency of archbacked nursing and licking and grooming on the offspring produces long-term effects in neurobiology and behavior (Liu et al.; Francis et al.). These data suggest that the manipulated arch-backed nursing receives more than unmanipulated offspring, consistent with the literature (Lee \& Williams, 1974). 
Importantly, we have not found a direct relationship between the effects of manipulation on the HPG axis parameters studied and plasma COR levels, so the effects of manipulation effects on the HPG axis may be mediated by some mechanism independent of the HPA axis. Thus, improvements in the HPG axis responses obtained in both the basal levels of LH and TES can not be attributed to the effects of postnatal stimulation HHA mediated, at least in the measured times.

On the other hand, we know the role of opioids (Petraglia et al.) and catecholamines in modulating the response of Leydig cells to stress. It is known that these hormones are markers agents in the testis and that there is a direct autonomic innervation via the spinal cord from the testicular interstitium that can be activated during stress (Lee et al., 2002). So, Bernier et al. (1984) found that catecholaminergic stimulation of Leydig cell steroidogenesis may inhibit them, thus leaving this route to be studied.

In conclusion, prenatal stress inhibits the HPG axis parameters and induces testicular apoptosis mediated by high levels of COR. Early postnatal stimulation reverses these effects by means other than the HPA axis.

CHEN CÁRDENAS, S. M.; MAYER, N.; ROMANINI, M. C.; ROLANDO, A. N.; LIAUDAT, A. C.; BRUN, N.; VIVAS, A.; GAUNA, H. F. \& RODRÍGUEZ, N. Respuestas reproductivas en ratas estresadas prenatalmente, expuestas a estimulación postnatal. Int. J. Morphol., 31(2):747-753, 2013

RESUMEN: El estrés en ratas preñadas altera el patrón de secreción de corticosterona (COR) materna la cual, por vía transplacentaria, produce una alteración del eje Hipotálamo-Hipófiso-Adrenal (HHA) fetal. El estrés prenatal producido durante la etapa crítica de diferenciación hipotalámica, está relacionado con la disminución de la fertilidad en las crías macho, por un aumento en el nivel de COR basal. Esta modificación podría inducir cambios a largo plazo en el proceso de apoptosis testicular. Sin embargo, la estimulación postnatal temprana mejora el comportamiento materno, revirtiendo las alteraciones producidas por el aumento de COR en las crías adultas. El objetivo fue investigar el efecto de la estimulación postnatal temprana sobre el eje Hipotálamo-Hipófiso-Gonadal (HHG) en ratas macho estresadas prenatalmente (EP), por inmovilización crónica durante las dos últimas semanas de la preñez. Se utilizaron crías de 3 meses de edad, que fueron divididas en 4 grupos: (a) individuos EP y sin estimulación postnatal; (b) individuos EP con estimulación postnatal; (c) individuos controles no estresados prenatalmente (CP) y sin estimulación postnatal; y (d) individuos CP con estimulación postnatal. En todos los grupos se midió COR, Testosterona (T) y Hormona Luteinizante (LH). Se determinaron la apoptosis y la Caspasa 3 testicular y el índice gonadosomático. Se concluye que el estrés prenatal por inmovilización aumenta los niveles de COR del eje HHA e inhibe el eje HHG obteniendo valores bajos de LH y T plasmáticas. Se observa disminución del tamaño testicular y aumento de la apoptosis de las células testiculares. Por otro lado, la estimulación postnatal temprana se traduce en un aumento del cuidado materno hacia la cría, lo que revierte los efectos producidos por el estrés prenatal sobre el eje HHG. Este efecto podría estar mediado por algún mecanismo independiente del eje HHA.

PALABRAS CLAVE: Estimulación postnatal temprana; Estrés prenatal; Eje HHA; Eje HHG; Ratas; Apoptosis.

\section{REFERENCES}

Allouche, L.; Hamadouche, M. \& Touabti, A.Chronic effect of low lead levels on sperm quality, gonadotropins and testosterone in albino rats. Exp. Toxicol. Pathol., 61(5):503-10, 2009.

Anderson, R. H.; Fleming, D. E.; Rhees, R. W. \& Kinghorm, E. Relationships between sexual activity, plasma testosterone, and volume of sexually dimorphic nucleus of the preoptica area in prenatally stressed and non-stressed rats. Brain Res., 370(1):1$10,1986$.

Arena, A. C. \& Pereira, 0. C. M. Neonatal inhalatory anesthetic exposure: reproductive changes in male rats. Comp. Biochem. Physiol. C Toxicol. Pharmacol., 133(4):633-40, 2002.

Barbazanges, A.; Vallée, M.; Mayo, W.; Day, J.; Simon, H.; Le Moal, M. \& Maccari, S. Early and later adoptions have different long-term effects on male rat's offspring. J. Neurosci., 16(23):7783-90, 1996.
Baum, M. J.; Brand, T.; Ooms, M.; Vreeburg, J. T. \& Slob, A. K. Immediate postnatal rise in whole body androgen content in male rats: correlation with increased testicular content and reduced body clearance of testosterone. Biol. Reprod., 38(5):980-6, 1988.

Bernier, M.; Gibb, W.; Collu, R. \& Ducharme, J. R. Effect of glucocorticoids on testosterone production by porcine Leydig cells in primary culture. Can. J. Physiol. Pharmacol., 62(9):1166-9, 1984.

Bertuzzi, M. 1.; Bensi, N.; Mayer, N.; Niebylski, A.; Armario, A. \& Gauna H. F. Renal mechanisms involved in the stress- induced antinatriuresis and antidiuresis in rats. Arch. Physiol. Biochem., 111(3):259-64, 2003.

Bonari, L.; Pinto, N.; Ahn, E.; Einarson, A.; Steiner, M. \& Koren, G. Perinatal risks of untreated depression during pregnancy. Can. J. Psychiatry, 49(11):726-35, 2004. 
CHEN CÁRDENAS, S. M.; MAYER, N.; ROMANINI, M. C.; ROLANDO, A. N.; LIAUDAT, A. C.; BRUN, N.; VIVAS, A.; GAUNA, H. F. \& RODRÍGUEZ, N. Reproductive response in offspring male rats exposed to prenatal stress and to early postnatal stimulation. Int. J. Morphol., 31(2):754-764, 2013.

Bullock, G. R. \& Petrusz, P. Techniques in immunocytochemistry. New York, Academic Press, 1983.

Chantal, H.; Arsaut, J.; Arnauld, E. \& Demotes-Mairnard, J. Transient neonatal elevation in hypothalamic estrogen receptor mRNA in prenatally-stressed male rats. Neurosci. Lett., 216(2):141-5, 1996.

Cory, S. \& Adams, J. M. The Bcl-2 family: regulators of the cellular life or death switch. Nat. Rev. Cancer, 2(9):647-56, 2002.

Dahlöf, L. G.; Hard, E. \& Larsson, K. Influence of maternal stress on the development of the fetal genital system. Physiol. Behav., 20(2):193-5, 1978.

De Kloet, E. R.; Rosenfeld, P.; Van Eekelen, J.; Sutanto, W. \& Levine, S. Stress, glucocorticoids and development. Prog. Brain Res., 73:101-20, 1988.

De Kloet, E. R. \& Reul, J. M. Feedback action and tonic influence of corticosteroids on brain function: a concept arising from the heterogeneity of brain receptor systems. Psychoneuroendocrinology, 12(2):83-105, 1987.

Dobson, H.; Ghuman, S.; Prabhakar, S. \& Smith, R. A. Conceptual model of the influence of stress on female reproduction. Reproduction, 125(2):151-63, 2003.

Döhler, K. D.; Hancke, J. L.; Srivastava, S. S.; Hofmann, C.; Shryne, J. E. \& Gorski, R. A. Participation of Estrogens in Female Sexual Differentiation of the Brain; Neuroanatomical, Neuroendocrine and Behavioral Evidence. Progr. Brain Res., 61:99-117, 1984.

Francis, D.; Diorio, J.; Liu, D. \& Meaney, M. J. Nongenomic transmission across generations of maternal behavior and stress responses in the rat. Science, 286(5442):1155-8, 1999.

Gao, H. B.; Tong, M. H.; Hu, Y. Q.; Guo, Q. S.; Ge, R. \& Hardy, M. P.Glucocorticoid induces apoptosis in rat leydig cells. Endocrinology, 143(1):130-8, 2002.

Gerardin, D. C.; Pereira, O. C.; Kempinas, W. G.; Florio, J. C.; Moreria, E. G. \& Bernardi, M. Sexual behavior, neuroendocrine, and neurochemical aspects in male rats exposed prenatally to stress. Physiol. Behav., 84(1):97-104, 2005.

Gorski, R. A. Hypothalamic imprinting by gonadal steroid hormones. Adv. Exp. Med. Biol., 511:57-70, 2002.

Gorski, R. A.; Harlan, R. E.; Jacobson, C. D. \& Southam A. M. Evidence for the existence of a sexually dimorphic nucleus in the preoptic area of the rat. J. Comp. Neurol., 193:529-39, 1980.

Hikim, A. P.; Lue, Y.; Yamamoto, C. M.; Vera, Y.; Rodriguez, S.; Yen, P. H.; et al. Key apoptotic pathways for heat-induced programmed germ cell death in the testis. Endocrinology, 144(7):3167-75, 2003.
Hobel, C. J.; Goldstein, A. \& Barrett, E. S. Psychosocial stress and pregnancy outcome. Clin. Obstet. Gynecol., 51(2):333-48, 2008.

Kim, J.; Gosh, S.; Weil, A. \& Zirkin, B. Caspase-3 and caspaseactivated deoxyribonuclease are associated with testicular germ cell apoptosis resultin from reduced intratesticular testosterone. Endocrinology, 142(9):3809-16, 2001.

Kinney, D. K.; Munir, K. M.; Crowley, D. J. \& Miller, A. M. Prenatal stress and risk for autism. Neuroscience \& Biobehavioral Reviews, 32(8):1519-32, 2008.

Krey, L.; Lu, K.; Butler, W.; Hotchkiss, J.; Piva, F. \& Knobil, E. Surgical disconnection of medial basal hypothalamus and pituitary in the rhesus monkey. II. Gh and cortisol secretion. Endocrinology, 96(5):1088-93, 1975.

Lalau, J. D.; Aubert, M. L.; Carmignac, D. F.; Grégoire, I. \& Dupouy, J. P. Reduction in testicular function in rats. II. Reduction by dexamethasone in fetal and neonatal rats. Neuroendocrinology, 51(3):289-93, 1990.

Le Moal, M. Mesolimbic dopaminergic neurons: functional and regulatory roles in: psychopharmacologic. The fourth generation of progress. New York, Raven Press, 1995. pp.283-5.

Lee, M. H. S. \& Williams, D. I. Changes in licking behavior of rat mother following handling of young. Anim. Behav., 22(3):679$81,1974$.

Lee, S.; Miselis, R. \& Rivier, C. Anatomical and funtional evidence for a neural hypothalamic-testicular pathway that is independent of the pituitary. Endocrinology, 143(11):4447-54, 2002.

Levin, R. \& Stern, J. M. Maternal influences on ontogeny of suckling and feeding rhythms in the rat. J. Comp. Physiol. Psychol., 89(7):711-21, 1975.

Liu, D.; Diorio, J.; Tannenbaum, B.; Caldji, Ch.; Francis, D.; Freedman, A.; et al. Maternal Care, Hippocampal Glucocorticoid Receptors, and Hypothalamic-PituitaryAdrenal Responses to Stress. Science, 277(5332):1659-61, 1997.

López-Calderon, A.; Gónzalez-Quijano, M. I.; Tresguerres, J. A. F. \& Ariznavarreta, C. Role of LHRH in the gonadotrophin response to restraint stress in intact male rats. J. Endocrinol., 124(2):241-6, 1990.

Lou, H. C.; Hansen, D.; Nordentoft, M.; Pryds, O. \& Jensen, J. Prenatal stressors of human life affect fetal brain development. Dev. Med. Child. Neurol., 36(9):826-32, 1994.

Maccari, S.; Darnaudery, M.; Morley-Fletcher, S.; Zuena, A.; Cinque, C. \& Van Reeth, O. Prenatal stress and long-term consequences: implications of glucocorticoid hormones. Neurosc. Biobehav. Rev., 27(1-2):119-27, 2003. 
Maccari, S.; Piazza, P. V.; Kabbaj, M.; Barbazanges, A.; Simon, H. \& Le Moal, M. Adoption reverses the long-term impairment in glucocorticoid feedback induced by prenatal stress. $J$. Neurosci., 15(1 Pt. 1):110-6, 1995.

Mayer, N.; Greco, C.; Bertuzzi, M.; Rodriguez, N.; Vivas, A. \& Gauna, H. F. Immobilization Stress Responses in Adult Rats Exposed In Utero to Immobilization. Stress Health, 27(2):e1e10, 2011.

Meaney, M. J.; Aitken, D.H. \& Sapolsky, R. M. Thyroid hormones influence the development of hippocampal glucocorticoid receptors in the rat: a mechanism for the effects of postnatal handling on the development of the adrenocortical stress response. Neuroendocrinology, 45(4):278-83, 1987.

Michajloskij, N.; Lichardus, B.; Kvetnasnsky, R. \& Ponrc, J. Effect of acute and repeated immobilization stress on food and water intake urine output and vasopressine changes in rats. Endocrinol. Exp., 22(3):143-57, 1988.

Montano, M. M.; Welshons, W. V. \& vom Saal, F. S. Free estradiol in serum and brain uptake of estradiol during fetal and neonatal sexual differentiation in female rats. Biol. Reprod., 53(5):1198207, 1995.

Moreno, R. D.; Lizama, C.; Urzua, N.; Vergara, S. P. \& Reyes, J. G. Caspase activation throughout the first wave of spermatogenesis in the rat. Cell Tissue Res., 325(3):533-40, 2006.

Nandi, S.; Banerjee, P. P. \& Zirkin, B. R. Germ cell apoptosis in the testes of Sprague Dawley rats following testosterone withdrawal by ethane1,2-dimethanesulfonate administration: relationship to Fas? Biol. Reprod., 61(1):70-5, 1999.

O’Donnell, D.; Larocque, S.; Seckl, J. R. \& Meaney, M. J. Postnatal handling alters glucocorticoid, but not mineralocorticoid messenger RNA expression in the hippocampus of adult rat. Brain Res. Mol. Brain Res., 26(1-2):242-8, 1994.

Ogawa, T.; Mikuni, M.; Kuroda, Y.; Muneoka, K.; Mori, J. M. \& Takahashi, K. Periodic maternal deprivation alters stress response in adult offspring: potentiates the negative feedback regulation of restraint stress-induced adrenocortical response and reduces the frequencies of open field-induced behaviors. Pharmacol. Biochem. Behav., 49(4):961-7, 1994.

Orth, J. M.; Weisz, J.; Ward, O. B. \& Ward, I. L. Environmental stress alters the developmental pattern of delta 5-3 betahydroxysteroid dehydrogenase activity in Leydig cells of fetal rats: a quantitative cytochemical study. Biol. Reprod., 28(3):625-31, 1983.

Patrick, J.; Challis, J.; Campbell, K.; Carmichael, L.; Richardson, B. \& Tevaarwerk, G. Effects of synthetic glucocorticoid administration on human fetal breathing movements at 34-35 weeks of gestational age. Am. J. Obstet. Gynecol., 139(3):3248, 1981.
Perakis, A. \& Stylianopoulou, F. Effects of a prenatal androgen peak on rat brain sexual differentiation. J. Endocrinol., 108(2):281-5, 1986.

Petraglia, F.; Vale, W. \& Rivier, C. Opioids act centrally to modulate stress-induced decreace in luteinizing hormon in the rats. Endocrinology, 119(6):2445-50, 1986.

Precht, D. H.; Andersen, P. K. \& Olsen, J. Severe life events and impaired fetal growth: a nation-wide study with complete follow-up. Acta Obstet. Gynecol. Scand., 86(3):266-75, 2007.

Rhees, R. W.; Davis, S. W.; Jacobson, N. A.; Ladle, D. R. \& Lephart, E. D. Effects of stress during pregnancy on maternal and fetal medial basal hypothalamic (NMH) 5a-reductase and aromatase activity. Soc. Neurosci., 22(3):1219, 1996.

Riccioli, A.; Salvati, L.; D’Alessio, A.; Starace, D.; Giampietri, C.; De Cesaris, P.; et al. The Fas system in the seminiferous epithelium and its possible extra-testicular role. Andrologia, 35(1):64-70, 2003.

Riccioli, A.; Starace, D.; D’Alessio, A.; Starace, D.; Giampietri, C.; De Cesaris, P.; et al. TNF-alpha and IFN-gamma regulate expression and function of the Fas system in the seminiferous epithelium. J. Immunol., 165(2):743-9, 2000.

Rodríguez, N.; Mayer, N. \& Gauna, H. F. Effects of prenatal stress on male offspring maturity. Biocell, 31(1):67-74, 2007.

Rooij, D. G. Stem cells in the testis. Int. J. Exp. Pathol., 79(2):67$80,1998$.

Ruwanpura, S. M.; McLachlan, R.; Staton, P.; Loveland, K. \& Meachem, S. J. Pathways involved in testicular germn cell apoptosis in immature rats after FSH suppression. $J$. Endocrinol., 197(1):35-43, 2008.

Ruwanpura, S. M.; McLachlan, R. \& Meachen, S. J. Hormonal regulation of male germ cell development $J$. Endocrinol., 205(2):117-31, 2010.

Shaha, C. Estrogens and spermatogenesis. In: Cheng, C. Y. (Ed.). Molecular Mechanisms of Spermatogenesis. Austin, Landes Biosciences, 2008. pp.42-64.

Silva, M.; Olivera, C.; Felicio, L.; Nasello, A. \& Bernardi, M. Perinatal treatment with picrotoxin induces sexual, behavior, and neuroendocrine changes in male rats. Pharmacol. Biochem. Behav., 60(1):203-8, 1998.

Sinha Hikim, A. P. \& Swerdloff, R. S. Hormonal and genetic control of germ cell apoptosis in the testis. Rev. Reprod., 4(1):3847, 1999.

Sinha Hikim, A. P.; Lue, Y.; Diaz-Romero, M.; Yen, P. H.; Wang, C. \& Swerdloff, R. S. Deciphering the pathways of germ cell apoptosis in the testis. J. Steroid Biochem. Mol. Biol., 85(25):175-82, 2003. 
CHEN CÁRdENAS, S. M.; MAYER, N.; ROMANINI, M. C.; ROLANDO, A. N.; LIAUDAT, A. C.; BRUN, N.; VIVAS, A.; GAUNA, H. F. \& RODRÍGUEZ, N. Reproductive response in offspring male rats exposed to prenatal stress and to early postnatal stimulation. Int. J. Morphol., 31(2):754-764, 2013.

Slob, A. K.; Ooms, M. P. \& Vreeburg, J. T. M. Prenatal and early postnatal sex differences in plasma and gonadal testosterone and plasma luteinizing hormone in female and male rats. $J$. Endocrinol., 87(1):81-7, 1980.

Szuran, T. F.; Pliska, V.; Pokorny, J. \& Welzl, H. Prenatal stress in rats: effects on plasma corticosterone, hippocampal glucocorticoid receptors, and maze performance. Physiol. Behav., 71(3-4):353-62, 2000.

Tripathi, R.; Mishra, D. P. \& Shaha, C. Male germ cell development: turning on the apoptotic pathways. J. Reprod. Immunol., 83(12):31-5, 2009.

Wakshalak, A. \& Weinstock, M. Neonatal handling reverses behavioral abnormalities induced in rats by prenatal stress. Physiol. Behav., 48(2):289-92, 1990.

Ward, I. L. \& Ward, O. B. Sexual behavior differentiation: effects of prenatal manipulations in rats. In: Adler, N.; Pfaff, D. \& Goy, R. W. (Eds.). Handbook of Behavioral Neurobiology, Reproduction. New York, Plenum, 1985. pp.1985.

Ward, I. L. \& Weisz, J. Differential effects of maternal stress on circulating levels of corticosterone, progesterone, and testosterone in male and female rat fetuses and their mothers. Endocrinology, 114(5):1635-44, 1984.

Ward, I. L. \& Weisz, J. Maternal stress alters plasma testosterone in fetal males. Science, 207(4428):328-9, 1980.

Ward, I. L. Prenatal stress feminizes and demasculinizes the behavior of males. Science, 175(4017):82-7, 1972.

Ward, I. L. The prenatal stress syndrome: current status. Psychoneuroendocrinology, 9(1):3-11, 1984.

Ward, O. B.; Ward, I. L.; Denning, J. H.; French, J. A. \& Hendricks, S. E. Postparturitional testosterone surge in male offspring of rats stressed and/or fed ethanol during late pregnancy. Horm. Behav., 41(2):229-35, 2002.
Weinstock, M. Does prenatal stress impair coping and regulation of hypothalamic-pituitary-adrenal axis? Neurosci. Behav. Rev., 21(1):1-10, 1997.

Weisz, J.; Brown, B. L. \& Ward, I. L. Maternal stress decreases steroid aromatase activity in brains of male and female rat fetuses. Neuroendocrinology, 35(5):374-9, 1982.

Young, K. A. \& Nelson, R. J. Mediation of seasonal testicular regression by apoptosis. Reproduction, 122(5):677-85, 2001.

Zarrow, M.; Philpott, J. \& Denenberg, V. Passage of C corticosterone from the rat mother to the foetus and neonate. Nature, 226(5250):1058-9, 1970.

Zhang, J.; Bahi, N.; Zubiaga, A. M.; Comella, J. X.; Llovera, M. \& Sanchis, D. Developmental silencing and independecy from E2F of apoptotic gene expression in postmitotic tissues. FEBS Lett., 585(30):5781-6, 2007.

Correspondence to:

Dra. Nancy Rodríguez

Departamento de Biología Molecular

Facultad de Ciencias Exactas

Universidad Nacional de Río Cuarto

ARGENTINA

Email: nmarioli@exa.unrc.edu.ar

Received: 23-08-2012

Accepted: 11-02-2013 